\title{
Research on the Models of After-class Activities Teaching and Innovative Talents Cultivation in Higher Vocational Colleges
}

\section{--Take Guangxi Eco-Engineering Vocational and Technical College as example}

\author{
Lina $\mathrm{Li}^{1}$, Wenbang $\mathrm{Wei}^{1, *}$ \\ ${ }^{1}$ Guangxi Eco-engineering Vocational and Technical College, Liuzhou, Guangxi, China \\ *Corresponding author
}

Keywords: Higher Vocational Colleges; After-class Activities; Talents Cultivation

\begin{abstract}
Nowadays, China is striving to develop vocational education and promote the craftsman spirit of the great power. Under this background, as the place of cultivating talents with high quality and applied skills, it is particularly important for higher vocational colleges to get the class activities and the after-class activities combined and build up the running model of cultivating innovative talents. This paper mainly explores the relationship between the teaching of after-class activities and the cultivation of innovative talents in higher vocational colleges and its effective methods. The paper takes the teaching of after-class activities as a carrier and gives suggestions on preliminarily building up running model of the after-class activities which is in line with the requirements of cultivating innovative talents according to author's working practice.
\end{abstract}

\section{Introduction}

According to Outline of National Medium and Long-Term Program for Education Reform and Development (2010-2020), Higher education must meet the needs of national and social development, follow the law of education and talent growth pattern, deepen the reform of education and teaching, innovate teaching methods, explore various cultivation ways, create a situation in which all kinds of talented people spring up. For higher vocational colleges in our country, the construction of university class culture, as an important part of advanced socialist culture, is an important method to execute college students' ideological and political education, cultivate comprehensive quality and improve their abilities.

\section{The Overview about the Class Teaching and the Cultivation of Innovative Talents}

In China, it mainly depends on class activities and after-class activities to carry out students' teaching work. The so called "class activities" is to set up relevant basic courses and specialized courses to let students master corresponding specialized knowledge according to different professional requirements and personnel training plans. It is the main way of teaching in higher vocational colleges. The "after-class activities" can be divided into three aspects: the construction of humanistic culture, the construction of spiritual culture and the construction of institution culture. Most vocational colleges only carry out limited student cultural and sports activities and social practice activities.

Innovative talents are the people who have innovative consciousness, spirit, thinking, knowledge and ability and has good personalities. They can get innovative achievements through their creative work. They are the people who contribute to social development and human progress in a particular field, industry, or job. The explanation of innovative talents in Chinese education circle is mainly from the views of creativity, innovative consciousness, innovative spirit and innovative abilities, etc. 


\section{The Cultivation of Innovative Talents Should Give Full Play to the Important Role of the After-Class Activities in College Students' Ideological and Political Education.}

In higher vocational colleges, there are many ways to cultivate innovative talents. However, due to the different levels of campus culture construction in higher vocational colleges, the main teaching method for most colleges is class activities which mainly focuses on improving teaching quality, the quality of teaching objectives, teaching reform and teaching evaluation.

At present, the teaching of after-class activities become more and more popular and mature in colleges. Students participate in a broad way and high cohesion. The specialization level, organization form and management system also have constantly improved. The author made a sample investigation in Guangxi Eco-engineering Vocational and Technical College: For the question "what do you think is the function of after-class activities?", 50.1 percent of the interviewees among 500 teachers and students had no clear ideas. 33.7 percent of the teachers thought the after-class activities lacked unified planning and the main task should be the teaching of class activities. For the question "Is it necessary to practice the credit system for the teaching of after-class activities? Any suggestions?"85 percent of interviewees thought it was quite necessary and 20.3 percent thought it didn't matter. 77.8 percent of teachers and students believed that the college focused on the teaching of class activities, ignored the distribution of credits in after-class activities. There was also a lack of scientific evaluation toward the application, calculation, examination and evaluation of credits. In the investigation of the emphasis degree of after-class activities, 64.3 percent of the interviewees thought the college lacked certain understanding toward the effects of the teaching of after-class activities. It led to the marginalized situation of hardware construction such as campus planning and teaching facilities. It concretely included the aspects like arrangement and use, policy arrangement, funds and staffing, etc.

It is important to make full use of the after-class activities in the ideological and political education of college students. Guangxi Eco-Engineering Vocational and Technical College pays attention in class, and also focuses on extending various approaches in ideological and political education. Firstly, the college deeply carries out social practice activities such as technological innovation, the volunteer service, work-study program and social investigation. In this way, college students' social practice security system can be established. The college also puts social practice into the teaching system, provides the necessary funds, explores and establishes new mechanisms for social practice combined with professional study, society service, work-study program, employment and innovation. It is the responsibility for the college to guide students to be educated, gain ability and learn to contribute. Secondly, the college energetically builds campus culture and a platform for campus culture. It will further standardize the management system of campus culture, and constantly enrich the content, adjust the form, give full play to the leading role of party organizations and student unions and the assistant role of student associations. The student will comprehensively receive quality education through a variety of academic, artistic and sports activities. The college will improve students' participation rate, respect students' individuality, give students relax campus cultural space to develop their personalities and make students' creativity be fully publicizing. The college should pay attention to carry out distinctive and attractive theme-education activities by combining with the traditional festivals and events like the Youth Day, the Party's Day, the National Day, the anniversary of the December 9th Movement, and the opening ceremony, the activity of joining the party, graduation, etc. The college will incorporate rich ideological education in campus culture activities to improve students' ideological and moral qualities; integrate rich science and technology culture education content to improve students' qualities of science and technology; Integrate rich humanity and art education content to improve students' cultural quality; Integrate the content of practice ability to improve students' social competitive ability; Integrate rich sports education content to enhance student's physique and the spirit of unity and cooperation. The college should vigorously implement the program of college students' quality development, guide and help students to improve their intelligent structure, and fully grow into talents.

Guangxi Eco-Engineering Vocational and Technical College positively takes effective actions in college students' clubs, community areas and the Internet to carry out ideological and political 
education. The college leads and manages students' clubs, sets up "department-class" two levels of community system, help students' organizations hire teachers, support and guide students' clubs to carry out activities independently. The college will mainly construct the management platform of students' living area, carry out series of students' dormitory culture activities and constructive activities like "learning dormitory", "civilization dormitory" and "star dormitory". The college will build "residence advisor-floor advisor-dormitory advisor" three levels of student self-management team network, give full play to the students' self education, self management and self service. The college will strengthen the construction of campus network, making the network an important way to highlight the themes of the times and carry out the ideological and political education of college students. The college will use campus network to provide services for students to study and live, and to educate and guide students. It will construct the websites like "School Workers Online", "Youth League Committee Work Online" into theme-education websites with ideological content, intellectual content and service content. The college will actively carry out lively ideological and political education on the internet to form the resultant power with traditional ideological and political education.

\section{The Exploration of the Running Model of After-Class Activities Which is in Line with the Cultivation of Innovative Talents}

From author's point of view, it is an extremely important project to further explore the running model of after-class activities which has its own characteristics, combines with class activities, is standardized managed and is in line with the cultivation of innovative talents. This paper, combining with the real teaching situation of Guangxi Eco-Engineering Vocational and the current condition of the development of after-class activities, explores from four main aspects: thinking innovation, method innovation, organization innovation and activity innovation. It aims to build the running model of after-class activities which is in line with the innovative talents cultivation and improve students' innovation consciousness, cultivate the innovative ability.

Strengthen Ideological Understanding and Establish New Ideas. The colleges should comprehensively implement the party's education policy, vigorously develop vocational education. They should intensify reform of teaching contents and teaching methods, make efforts to build a new talents cultivation model, play their own advantages, highlight the school characteristics and comprehensively improve the quality of talents cultivation. Take Guangxi Eco-Engineering Vocational and Technical College as example. It sets unified and instructional overall scheme of talents cultivation by the teaching department. Then each major teaching department makes a plan in detail according to the specific requirements. What's more, the colleges should actively explore and develop visual teaching, let the students practice by themselves, let the textbook knowledge become "visible" and "touchable", hold exhibitions of visual teaching achievements to make students feel a sense of accomplishment. For example, in Guangxi Eco-Engineering Vocational and Technical College, there will be meetings of teaching arrangement, meetings of teaching summary and teaching competitions each semester. These activities unify the thoughts of teachers, teaching staff, administrative personnel and students together, let class activities and after-class activities complement each other and promote each other, and raise after-class activities to the level of talents cultivation.

Improve Management Mechanism and Set Up Incentive Ideas. In order to set rules for after-class activities to follow, the higher vocational colleges should focus on the aspects of the activity running and construction of the teaching team. While setting up the incentive mechanism of the after-class activities, colleges should set up the concept of motivation. Take Guangxi Eco-Engineering Vocational and Technical College as example. It raises many incentive methods for teachers, especially for young teachers in the aspects like professional title promotion and annual appraisal. Teachers who take the responsibility for students' clubs and teachers who are in charge of classes can enjoy priority in title promotion, annual teaching, and teacher's appraisal, etc. In doing so, the colleges can both mobilize the enthusiasm of teachers and students, making them understand the 
importance of after-class activities, and get them involved in the after-class activities actively. In this case, the two kinds of teaching activities can truly complement each other and promote each other.

Further Innovate the Content and Forms of After-Class Activities. Take Colorful Activities of Culture, Sports and Science and Technology as Carrier, Cultivate Students' Innovative Ability. The colleges should improve students' interest and motivation by taking colorful activities of culture, sports and science and technology as carrier. There are many activities held by youth league committee, the department of students' affairs and student clubs in Guangxi Eco-Engineering Vocational and Technical College. For example, some cultural activities like the Art Festival, competitions of painting and calligraphy and photography competitions. There are also some sports competitions, sports clubs, science competitions and outward bound activities. These activities can keep improving the students' participation consciousness, develop their interest, constantly improve the image thinking ability, enhance the training of innovation thinking, cultivate the spirit and the innovation consciousness. At present, the college has formed some representative after-class activities. Such as Cultural Art Festival, the fashion show of environmental protection, discussion activities of employment and entrepreneurship, the plant identification activity, the outward bound activities of youth Marxism, etc.

Take Social Practice Activities as Carrier, Cultivate Students' Innovative Ability. Practice is the source of innovation. Higher vocational colleges should work hard in practice content and form, insist on combining social practice with specialized study, social service, work-study system, and entrepreneurship and employment. Take Guangxi Eco-Engineering Vocational and Technical College as example. Each year, the college organizes teachers and students to participate in the social practice activity which need doctors, scientists and college students to go to the countryside to spread scientific and literacy knowledge and offer medical service to farmers. It combines with the characteristics of the school education (forestry), put professional knowledge into the practice of life. The college also organizes young volunteers to carry out a series of practical activities such as "Civilized Traffic Persuasion", "Love Bird Week" and "Red Ribbon". By conducting both organized and spontaneous activities, both concentrated and dispersed activities, and both general and detailed activities, colleges can actively explore new carrier to develop the innovative ability of students' practice.

Establish Relevant Sane Guarantee System. In author's point of view, to establish and improve relevant guarantee system of the innovative ability cultivation in after-class activities, and do a good job in development planning, institution construction, work coordination, incentive mechanism and so on, the colleges should establish material safeguard mechanism of funds investment and hardware environment construction, establish and improve incentive mechanism and mechanism for examination and assessment of the quality of the after-class activities to attract college students and teachers to participate in the activities.

Above all, the author thinks that cultivating college students' innovation ability is a systematic project, and after-class activities provides a platform to improve college students' innovation ability in higher vocational colleges. It is the supplement and extension of class activities. China is vigorously developing vocational education and advocating the craftsman spirit of the great power. Under this background, the investigation and construction of the running model of after-class activities in higher vocational colleges will make it the main method to cultivate innovative students.

\section{Acknowledgement}

Project Fund: The Vocational Education and Teaching Reform Project of Guangxi in 2015" The Construction of Campus Culture Construction and Innovative Talents Cultivation System in Higher Vocational Colleges "(No.GXGZJG2015B193 ). 


\section{References}

[1]The National Medium and Long-Term Plan for Reform and Development of Education (2010-2020), 2012,09.

[2] Yanmin Zhao, The Role of After-Class Activities in Cultivation of University Students' Innovation Ability, Liaocheng University http://www.doc88.com/p-4485901220737.htm

[3]The Study on After-Class Activities in Cultivation of University Students' Innovation Ability, http://www.doc88.com/p-280362748415.html。

[4]Jie Shi, Wen Lun,Xianqi Zhu. The Connotation and Structure of Campus Culture [J]. Chinese Higher Education Research,2015(5).

[5]Lijun Tong. The Construction of Campus Culture and the Cultivation of Innovative talents in Higher Vocational Colleges [J] The Science Education Article Collects, 2013, (5) issue of the first ten days 